Jurnal Hunafa: Studia Islamika, Volume 16, Number 2, p. 1- 150

E-ISSN: 2355-7710

P-ISSN: 1411-125X

\title{
CURRICULUM DEVELOPMENT IN IMPROVING STUDENTS' ISLAMIC CHARACTER
}

Moh. Hakiki Rizkyan Syah ${ }^{1}$

${ }^{1}$ Universitas Muhammadiyah Sidoarjo, Sidoarjo, hakikiriskiansyah@gmail.com

\begin{abstract}
Curriculum development in improving Islamic character becomes a focus of attention in schools, especially schools with Islamic nuance in an effort to build Islamic students. The inclusion of this Islamic character development aims to produce graduates who have moral values that uphold Islamic values that have a commendable attitude in society, good discipline, honest, independent, and other positive attitudes that are embedded in students. This research is field research that serve the data with analytical analysis. The study used psychological and sociological approach. The result found the inclusion of Islamic character, such as faith and piety, honesty, trustworthy, fair, responsible, sympathetic, political and others, in the curriculum development.
\end{abstract}

Keywords: curriculum, character, Islamic

\begin{abstract}
Abstrak. Pengembangan kurikulum dalam meningkatkan karakter islami menjadi fokus perhatian di sekolah-sekolah, khususnya sekolah yang bernuansa islami dalam upaya untuk membangun keislaman peserta didik. Dimasukkannya pengembangan karakter islami ini bertujuan untuk menghasilkan lulusan yang berakhlaqul karimah yang menjunjung tinggi nilai-nilai islami yang mempunyai sikap terpuji dalam masyarakat, baik sikap disiplin, jujur, mandiri, dan sikap positif lainnya yaqng tertanam pada diri siswa. Penelitian ini
\end{abstract}


merupakan penelitian lapangan yang menyajikan data dalam bentuk analisis deskriptif. Penelitian ini menggunakan pendekatan psikologikal dan sosiologikal. Dalam pengembangannya penelitian ini menemukan adanya pengembangan karakter-karakter Islam, seperti iman dan percaya, jujur, amanah, adil, bertanggung jawab, simpatik, politik, dan sebagainya, di dalam pengembangan kurikulum.

Kata kunci: kurikulum, karakter, Islami

\section{Introduction}

Based on our constitution, No. 20 of 2003, concerning UUSPN article 3 explained that "National education functions to develop capabilities and shape the character and civilization of a dignified nation in order to educate the life of the nation, aiming at developing the potential of learners to become human beings who believe in and devote to God Almighty, moral noble, healthy, knowledgeable, capable, creative, independent, and become citizens who are democratic and responsible ". Article 1 of the Act also explains that education is "a conscious and planned effort to create an atmosphere of learning and learning process so that students actively develop their potential to have religious spiritual strength, self-control, personality, intelligence, noble character, and the skills needed by them, community, nation and state."

The formulation of the objectives of national education reflects the general picture of the Indonesian people who is expected and must be produced through the implementation of each educational program. Therefore, the formulation of the objectives of national education becomes the basis in developing the cultural values

\footnotetext{
${ }^{1}$ Sri Haryati, “Pendidikan Karakter dalam Kurikulum 2013." (Bachelor Scientific Paper, Universitas Trunojoyo Madura)
} 
of the nation's character in schools based on Pancasila, the 1945 Constitution and the culture of the Indonesian nation.

Character education can be integrated in learning in each subject. Learning materials related to norms or values in each subject need to be developed, made explicit, related to the context of daily life. Therefore, learning character values should not only be given at the cognitive level, but touches on internalization and real practice in the lives of daily students at school and in the community. ${ }^{2}$

Associated with the forms of moral decline that often occurs in the world of education itself include gaps and deviations, such as ethics in socializing, fighting, pornography, drugs, so as to cause a lot of embarrassing acts of deeds far from the noble morality circulating in the community which is always circulating in society uphold religious and cultural values. Education which is currently only seems to pursue the value of graduation and less attention to the values of Islamic religion. ${ }^{3}$

Education is generally understood as a process of human social maturity towards the proper level, namely the creation of whole human beings, including the balance of aspects of humanity that are in harmony with both physically and mentally. It contains the meaning associated with the purpose of maintaining and developing the nature and potential towards Insan Kamil. ${ }^{4}$

The multidimensional crisis that has plagued the nation and state of Indonesia at the moment if the root of the problem is sought is sourced from weak nation and character building (weak character and mental development). ${ }^{5}$ The rise of various kinds of crime, brawls between students and the increasing number of young people

\footnotetext{
${ }^{2}$ Agus Zaenal Fitri. Pendidikan Karakter Berbasis Nilai dan Etika di Sekolah. (Yogyakarta: Ar-Ruzz, 2012)

${ }^{3}$ Safrijal, “Model Pembelajaran Inkuiri Terinternalisasi Ayat-Ayat Al-Qur'an untuk Meningkatkan Pemahaman Konsep Larutan Penyangga dan Karakter Islami Siswa”. Lantanida Journal, Vol. 3 No. 1, (2015)

${ }^{4}$ Ahmadi, Islam Sebagai Paradigma Ilmu Pendidikan, (Yogyakarta: Aditya Media, 1992), 16.

${ }^{5}$ Haidar Putra Daulay, Pendidikan Islam dalam Sistem Pendidikan Nasional, (Jakarta: Kencana Prenada Media Group, 2007), 216.
} 
involved in the use of illegal drugs, is an indication of moral decline. Therefore, the formation of character and personality of children in accordance with religious values and human values becomes a need and necessity. The phenomenon of the decline.

The phenomenon of the decline in national character in the country can be caused by the weakness of character education in continuing national values at the transition between generations. In addition, the weak implementation of character values in government and social institutions coupled with the flow of globalization has obscured the moral values of the nation's culture which are actually highly valued. As a result, non-normative behaviors penetrate deeper and result in damaging national life. Citizens who are democratic, virtuous, responsible for the welfare of the nation, have good morals, have democratic morals, as stated in Law No. 2 of 1989, Law No. 20 of 2003, have not been realized as expected. ${ }^{6}$

\section{Method}

This type of research is field research that is a type of research based on data obtained directly from the research site in the field and is analytic descriptive. This study uses a psychological and sociological approach. The problem raised is curriculum development in improving the Islamic character of students. Data analysis was performed by descriptive qualitative method. The results of the analysis show that the application of Islamic character values education in schools can help foster the Islamic character of students by highlighting religious values and adherence to parents or teachers. The basic concept of Islamic character education is based on the vision, mission and goals of the school which are implemented into the curriculum and subjects, the culture of the school both in the environment of teachers and students and self-development through habituation programs and

\footnotetext{
${ }^{6}$ Supiana and Rahmat Sugiharto. "Pembentukan Nilai-nilai Karakter Islami Siswa Melalui Metoe Pembiasaan.” Jurnal Educan Vol 1, No 1 (2017)
} 
intellectual development of students. The concept of Islamic character values education in curriculum development by incorporating Islamic character values into all subjects. The values of Islamic characters that are inculcated are religious values, independent values, values that value achievements, values of curiosity, values of patriotism and creative values.

\section{Discussion}

Definition of curriculum

The definition of the curriculum when viewed in terms of etymology comes from Latin, namely "curere" or "curriculum" which all have the meaning of the word "a running course special a chariot race course". Whereas in French it is called "courir" meaning "to run", and this term is used for a number of "courses" or subjects that must be taken to achieve a degree or diploma. ${ }^{7}$ Furthermore, the curriculum has developed into the subject matter studied (the course of study). ${ }^{8}$

In Arabic the curriculum is defined as manhaj, which is a clear path, or a bright path that is traversed by humans in their fields of life. ${ }^{9}$ While Nasution was quoted by Armai Arief conclude some of the interpretations of the curriculum include: first, curriculum as a product. Second, curriculum as a program. Third, curriculum as things that are not learned by students. Fourth, the curriculum is seen as a student experience. ${ }^{10}$

\footnotetext{
${ }^{7}$ S. Nasution, Pengembangan Kurikulum, (Bandung: Citra Aditya Bhakti, 1998), 9

${ }^{8}$ Mukhtar, Merambah Manajemen Baru Pendidikan Tinggi Islam, (Jakatra: cv. Misaka Ghazila,

${ }^{9}$ Muhaimin, Pengembangan Kurikulum Pendidikan Agama Islam Di Sekolah, Madrasah, dan Perguruan Tinggi, (Jakarta: Rajawali Press, 2005), 1

${ }^{10}$ Armai Arief, Pengantar Ilmu Dan Metodologi Pendidikan Islam, (Jakarta: Ciputat Press), 31
} 2003), 63 
Furthermore, integrating the term curriculum is also interpreted as all learning material that must be presented in the educational process in an initial education system. ${ }^{11}$

From the above understanding it can be interpreted specifically that curriculum is a set of plans and content arrangements and also as teaching material used as a teaching guide covering four curriculum components including objectives, contents, organization, and strategy.

\section{Curriculum Development}

The term curriculum development comes from the words development and curriculum. The term "development" in this paper is intended as a systematic, planned, methodological, and comprehensive effort with the aim of criticizing, renewing, and perfecting something that already exists ${ }^{12}$. While the definition of curriculum as a construct or concept, a verbalization of an extremely complex idea or set of ideas. ${ }^{13}$ From the notion of development and curriculum, what is meant by "curriculum development," in this paper is "a planned, systematic, methodological, and comprehensive effort aimed at criticizing, renewing, and refining pre-existing curricula", which in special contexts is focused on developing students' Character. ${ }^{14}$

The definition of Character-Based Curriculum Development is a "planned, systematic, methodological, and comprehensive effort aimed at criticizing, renewing, and perfecting the existing curriculum towards a curriculum that is oriented towards exploring, developing, and strengthening the character of

\footnotetext{
${ }^{11}$ M. srifin, ilmu pendidikan islam, (Jakarta: Bumi Aksara, 1991), 183

${ }^{12}$ Hamalik Oemar, Psikologi Belajar dan Mengajar, (Bandung: Sinar Baru Algesindo, 2000)

${ }^{13}$ P.F. Olivia, Developing the Curriculum $4^{\text {th }}$ ed, (New York: NY Longman, 1997), 12

${ }^{14}$ Agus Salim Mansyur, "Pengembangan Kurikulum Berbasis Karakter: Konsepsi Dan Implmentasinya”, Jurnal Pendidikan Universitas Garut. Vol. 01, No. 01, (2007); 1-9
} 
Participants educate as individuals, professionals, and citizens of the Indonesian nation."15

\section{Islamic character}

In language the character comes from the Latin "Kharassein", "Kharax", in English: "character" and Indonesian "karakter". The Greek "character from charassein means to make sharp, to make deep. If in the Poerwadarminta dictionary, character is defined as character, mental characteristics, character that distinguishes one person from another. Personal characteristics include things such as behavior, habits, likes, dislikes, abilities, tendencies, potential, values, and patterns of thought. ${ }^{16}$ Imam Ghazali considers that character is closer to morals, namely human spontaneity in attitude or deeds that have been integrated in humans so that when they appear they do not need to think about it.

According to the Ministry of Education, there are eighteen characters which want to be developed in education. These values are sourced from religion, Pancasila, culture and national education goals. The eighteen values are religious, honest, tolerance, discipline, hard work, creative, independent, democratic, curiosity, national spirit, love of the motherland, respect for achievement, friendly and communicative, love peace, love to read, care for the environment, social care and responsibility. ${ }^{17}$ These character values have actually been explained in the Qur'an that is drawn in the Prophet Muhammad. ${ }^{18}$

Character education in Islam is essentially as a vehicle for the formation of human beings with high morality. In the teachings of Islamic moral or social morals

\footnotetext{
${ }^{15} \mathrm{ibid}$

${ }^{16}$ Dian Andayani, Pendidikan Karakter Perspektif Islam, (Bandung:PT Rosadakarya2013), 11.

${ }^{17}$ Balitbang Kurikulum Kemendiknas, Pengembangan Pendidikan Kultur dan Karakter Bangsa, 9-10

${ }^{18}$ Toshihiko Izutsu, Ethic Religious Concepts in the Qur'an (Montreal: McGill-Queen's University
} Press, 2002), 203. 
cannot be separated from the faith. Faith is a confession of the heart. Morals are the reflection of faith in the form of behavior, speech, and attitudes or in other words morality is good deeds. Faith is meaningful (abstract) while morals is proof of faith in the form of actions carried out with awareness and because of Allah alone. ${ }^{19}$

Character education has long been shared implicitly in the administration of national education, in relation to character education, there are noble values including faith and piety, honesty, trustworthy, fair, responsible, sympathetic, political and others. ${ }^{20}$

\section{References}

Mansyur, Agus Salim, "Pengembangan Kurikulum Berbasis Karakter: Konsepsi Dan Implmentasinya." Jurnal Pendidikan Universitas Garut, Vol. 01, No. 01, 2007, pp. $1-9$

Ahmadi, Islam sebagai Paradigma Ilmu Pendidikan, Yogyakarta: Aditya Media, 1992.

Arief, Armai, Pengantar Ilmu dan Metodologi Pendidikan Islam, Jakarta: Ciputat Press, 2002.

Balitbang of the Ministry of National Education Curriculum, Development of Culture and National Character Education, 9-10

Andayani, Dian, Pendidikan Karakter Perspektif Islam, Bandung: PT Rosadakarya, 2013.

Fitri, Agus Zaenal, Pendidikan Karakter Berbasis Nilai dan Etika di Sekolah, Yogyakarta: Ar-Ruzz, 2012.

Fitri, Agus Zainul, Reinventing Human Character: Pendidikan Karakter Berbasis Nilai and Etika di Sekolah, Jogjakarta: Ar-Ruzz Media, 2010.

Daulay, Haidar Putra, Pendidikan Islam dalam Sistem Pendidikan Nasional, Jakarta: Kencana Prenada Media Group, 2007

Srifin, M., Ilmu Pendidikan Islam, Jakarta: Earth Literacy, 1991

\footnotetext{
${ }^{19}$ Fitri, Agus Zainul, Reinventing Human Character: Pendidikan Karakter Berbasis Nilai and Etika di Sekolah,( Jogjakarta: Ar-Ruzz Media, 2010).

${ }^{20}$ Yaumi, Muhammad, Prinsip-Prinsip Desain Pembelajaran, (Jakarta: Kencana Prenadamedia Group, 2013)
} 
Jurnal Hunafa: Studia Islamika, Volume 16, Number 2, p. 1- 150

E-ISSN: 2355-7710

P-ISSN: 1411-125X

Muhaimin, Pengembangan Kurikulum Pendidikan Agama Islam Di Sekolah, Madrasah, dan Perguruan Tinggi, Jakarta: Rajawali Press, 2005.

Mukhtar, Merambah Manajemen Baru Pendidikan Tinggi Islam, Jakatra: CV. Misaka Ghazila, 2003.

Nasution, S., Pengembangan Kurikulum, Bandung: Citra Aditya Bhakti, 1998.

Safrijal, "Model Pembelajaran Inkuiri Terinternalisasi Ayat-Ayat Al-Qur'an Untuk Meningkatkan Pemahaman Konsep Larutan Penyangga dan Karakter Islami Siswa." Lanthanide Journal, Vol. 3 No. 1, 2015

Izutsu, Toshihiko, Ethico Religious Concepts in the Qur'an, Montreal: McGill-Queen's University Press, 2002.

Haryati, Sri. "Pendidikan Karakter dalam Kurikulum 2013”, Bachelor's Scientific Paper, Madura: Universitas Trunojoyo Madura.

Supiana and Sugiharto, "Rahmat. Pembentukan Nilai-nilai Karakter Islami Siswa Melalui Metoe Pembiasaan." Educan Journal, Vol 1, No 1, 2017

Yaumi, Muhammad, Prinsip-Prinsip Desain Pembelajaran, Jakarta: Kencana Prenadamedia Group, 2013. 